\title{
PENDUDUK DAN KEBUTUHAN PANGAN DI INDONESIA 2005-2050: SUATU PROYEKSI
}

\author{
Rachmini Saparita (rsaparita@yahoo.com) \\ Balai Besar Pengembangan Teknologi Tepat Guna LIPI Subang
}

\begin{abstract}
The aim of this study was to identify population growth during 1960-2002, and also its projection until 2050. The study also analyzed its impact and look for alternative policies in overcoming the problem to fulfill food security. The model used in the study was dynamic system approach which analyzes previous events to predict the upcoming condition. The study result indicated that the population increased rapidly, and was predicted would continue growing fast. Population growth and food requirement per capita determined the level of requirement of total food. To reach food security, the requirement would be better fulfilling by domestic production and did not depend on import. The policy alternative, which consisted of farm harvest enlargement and technological adoptions, were proposed to meet domestic production exceeding the requirement.
\end{abstract}

Key words: food requirement, food security, population

Indonesia merupakan negara dengan jumlah penduduk yang tinggi dan juga mempunyai lahan pertanian yang cukup luas. Laju pertumbuhan penduduk yang cukup tinggi pada masa orde lama, sementara produksi pertanian saat itu tidak mencukupi kebutuhan pangan penduduk, menyebabkan terjadinya kekurangan pangan dan penduduk bertambah miskin.

Berbagai program telah dijalankan pemerintah Indonesia untuk mengatasi masalah di atas. Program pembangunan ekonomi telah dijalankan, khususnya dimulai pada masa orde baru. Prioritas pembangunan ekonomi pada Pelita I bertumpu pada pembangunan pertanian. Hasil pembangunan ekonomi yang paling nyata adalah tercapainya program swasembada pangan (beras) pada tahun 1984.

Program lain yang dijalankan pemerintah adalah program kependudukan untuk pengaturan kelahiran bayi (keluarga berencana). Program tersebut telah berjalan sejak Pelita I dan telah berdampak pada penurunan tingkat fertilitas total wanita Indonesia. Mulai tahun 1999 tingkat fertilitas total wanita Indonesia telah mencapai 2,1. Artinya satu orang wanita melahirkan anaknya rata-rata 2,1 orang.

Beralihnya program prioritas pemerintah pada pembangunan industri di Pelita III, khususnya setelah swasembada beras tercapai, berdampak pada besarnya pasokan pangan dari domestik. Meskipun produksi pertanian masih menujukkan peningkatan, namun laju produksinya tidak sebesar laju kebutuhan konsumsi (beras), khususnya setelah tahun 1994. Peningkatan kebutuhan konsumsi tersebut disebabkan oleh pesatnya laju pertumbuhan penduduk dan meningkatnya kebutuhan pangan per kapita, sehingga kebutuhan pangan lebih besar dari produksi pertanian yang dihasilkan. Untuk memenuhi kebutuhan tersebut, pemerintah mengimpor bahan pangan, khususnya beras bahkan impor beras terus berlangsung sampai saat ini. 
Tergantungnya Indonesia pada pangan impor menyebabkan keraguan terhadap ketahanan pangan yang ingin diraih. Ketika cadangan devisa mencukupi, impor pangan tidak menjadi masalah besar. Namun apabila tidak ada cadangan devisa, atau apabila cadangan devisa yang ada tersebut adalah hasil pinjaman, maka kondisi ini akan sangat memprihatinkan. Jika demikian yang terjadi, sampai kapankah Indonesia dapat bertahan dalam memenuhi kebutuhan pangan penduduk.

Kajian ini bertujuan menelaah perkembangan populasi penduduk selama tahun 1960-2002, serta proyeksi perkembangan tersebut sampai tahun 2050. Penelitian juga menganalisis dampak perkembangan tersebut pada kebutuhan pangan nasional, dan mencari alternatif kebijakan yang dapat dijalankan dalam mengatasi masalah yang muncul untuk mencapai ketahanan pangan yang tangguh.

\section{METODOLOGI}

Kajian yang merupakan bagian dari penelitian pembangunan pertanian dengan memanfaatkan model pembangunan pertanian yang telah dikembangkan Saparita (2004). Model yang dibangun menggunakan pendekatan system dynamics, yang bersifat deskriptif-analitik ex ante, yaitu menganalisis peristiwa/kejadian sebelum peristiwa tersebut terjadi. Hasil simulasi model dapat menganalisis perkembangan penduduk dan kebutuhan pangan dari produksi domestik, baik pada masa lalu (1960-2004), maupun masa datang (2005-2050). Struktur sistem yang dibangun pada proses pembangunan pertanian di Indonesia seperti struktur yang diajukan (Saparita, Arief, Nazif, Natawidjadja, \& Tasrif, 2003).

Hubungan kausal antara variabel utama yang menjadi pokok bahasan penelitian ini, yaitu populasi penduduk, kebutuhan pangan, produksi pertanian dan pasokan pangan dapat dilihat pada Gambar 1. Variabel-variabel tersebut diasumsikan saling mempengaruhi satu dengan lainnya. Populasi penduduk yang merupakan penyedia tenaga kerja (pertanian) mempengaruhi luas lahan pertanian melalui laju penyusutan lahan pertanian. Lahan dan tenaga kerja pertanian merupakan faktor yang mempengaruhi produksi pertanian, sementara itu jumlah produksi pertanian mempengaruhi (pasokan) konsumsi pangan. Besarnya produksi mempengaruhi alokasi konsumsi pangan, yang pada akhirnya menentukan jumlah ketersediaan pangan dari domestik. Pasokan (konsumsi) pangan ditentukan oleh besarnya alokasi konsumsi dan impor pangan ketika ketersediaan pangan lebih kecil dari kebutuhan pangan penduduk. Kebutuhan pangan penduduk ditentukan oleh besarnya populasi penduduk, disamping tingkat pendapatan penduduk itu sendiri. Sementara populasi penduduk juga dipengaruhi pula oleh kondisi pasokan pangan. Pesatnya perkembangan penduduk dapat berpengaruh secara negatif pada ketersediaan konsumsi pangan per kapita, yang nantinya mempengaruhi kebutuhan pangan penduduk.

Data kuantitatif untuk menelaah kondisi yang terjadi di lapangan adalah data selama periode tahun 1960-2002. Tahun awal pengamatan ditentukan tahun 1960 dengan asumsi pembangunan (pertanian) dimulai oleh Pemerintah Indonesia "Modern" (Orde Lama), setelah negara Indonesia berhenti dari revolusi memperjuangkan kemerdekaan dan peperangan. Dari sisi ekonomi, hal tersebut ditandai dengan mulai adanya peningkatan kontribusi berbagai sektor pada ekonomi negara yaitu Produk Domestik Bruto - PDB (BPS, 1973). Karena data pada tahun 1960 untuk variabelvariabel yang terlibat belum lengkap, maka beberapa variabel sebagai parameter model yang data sekundernya tidak tersedia diestimasi dengan beberapa metode statistik dan ekonometrik. 


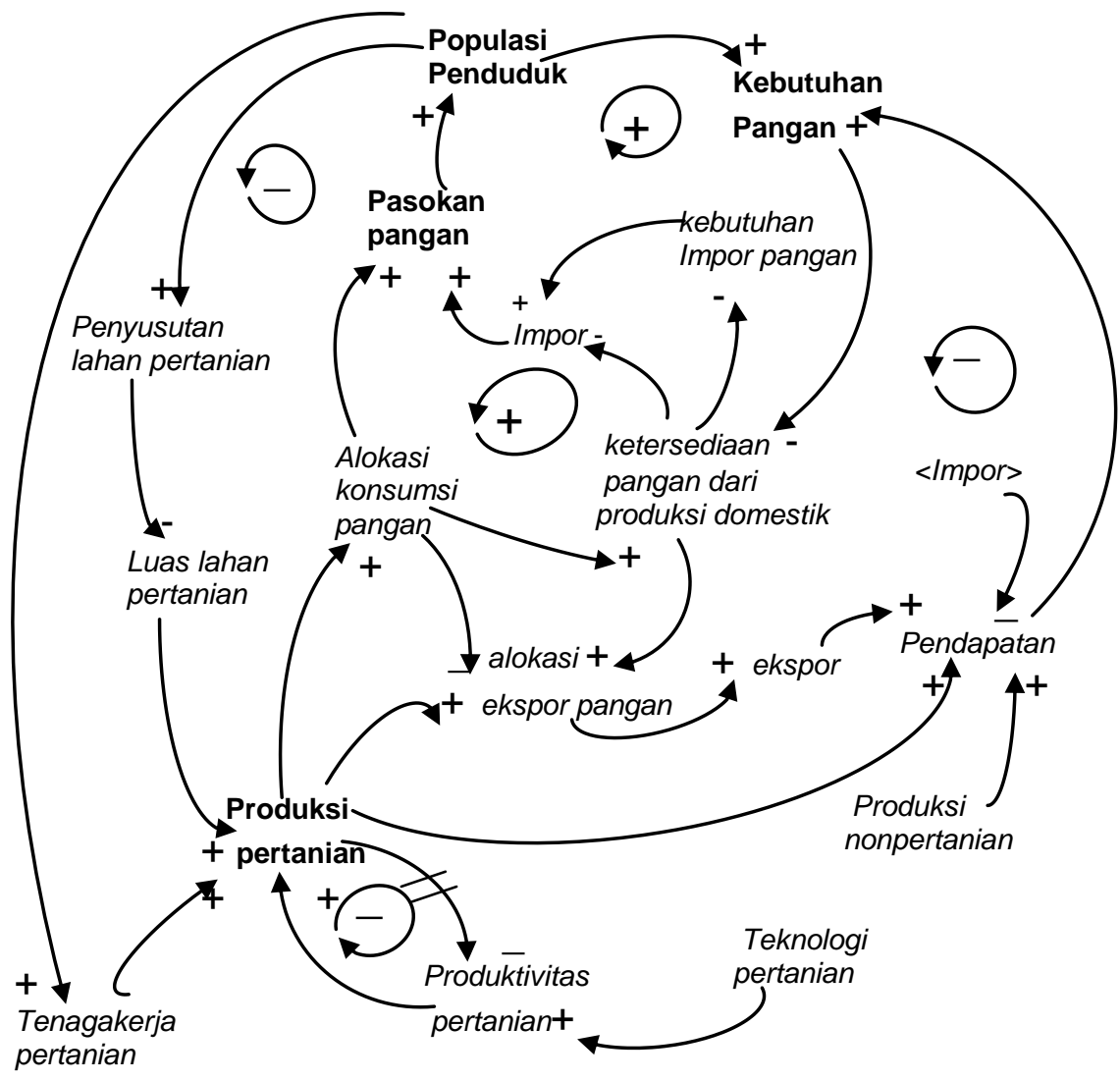

Gambar 1. Hubungan kausal variabel populasi penduduk, kebutuhan pangan, produksi pertanian dan pasokan pangan *)

*) Keterangan Gambar 1:

1. Anak panah yang bertanda positif dapat berarti sebab mempengaruhi akibat dengan perubahan yang sama, atau sebab akan menambah akibat.

2. Anak panah yang bertanda negatif dapat berarti sebab mempengaruhi akibat dengan perubahan yang berlawanan, atau sebab akan mengurangi akibat.

3. Variabel dengan huruf tebal adalah variabel utama

4. Keberadaan variabel utama tersebut sangat dipengaruhi dan mempengaruhi variabel pendukung lainnya (dicetak miring).

Pemilihan tanaman pangan sebagai wakil sektor pertanian karena kontribusi rata-rata selama tahun 1960-2002 ini masih di atas $60 \%$. Data penduduk dan data produksi pertanian tanaman pangan bersumber dari hasil sensus penduduk dan sensus pertanian serta survey yang telah dilaporkan oleh BPS. Data produksi pertanian dalam satuan ton, diambil dari data panen tanaman pangan (padi dan palawija). Data tersebut telah dihitung ke dalam kalori oleh Saparita (2004) berdasarkan nilai konversi yang dilakukan oleh Simatupang (1989). Data kuantitatif diperlukan sebagai referensi model yang dikembangkan. 


\section{HASIL DAN PEMBAHASAN}

\section{Perkembangan Populasi Penduduk dan Kebutuhan Pangan: 1960-2002}

\section{Perkembangan Penduduk di Indonesia: 1960-2002}

Berdasarkan hasil sensus penduduk yang telah dilakukan oleh BPS dalam beberapa dekade terakhir, penduduk Indonesia mengalami perkembangan yang cukup pesat (Gambar 2).

Perkembangan penduduk tersebut menentukan besarnya kebutuhan pangan.

\section{Perkembangan Kebutuhan Pangan Penduduk: 1960-2002}

Kebutuhan pangan penduduk Indonesia dihitung dari besarnya kecukupan gizi seperti yang disyaratkan Widyakarya Pangan dan Gizi ke V (LIPI, 1993) yang dilaporkan BPS (1999), yaitu sebesar 2150 kalori per kapita per hari, atau menjadi 774 kkal/tahun/kapita, dan meningkat menjadi 2500 kalori/hari/kapita atau 900 kkal/tahun/kapita (LIPI, 2000). Apabila diasumsikan bahwa kebutuhan penduduk sebelum 1993 sebesar 774 kkal/tahun/kapita dan menjadi 900 kkal/tahun/kapita setelah itu, dengan perkembangan penduduk seperti pada Gambar 2, maka perkembangan kebutuhan pangan penduduk dapat dilihat pada Gambar 3. Sementara data BPS tentang produksi pertanian yang telah diolah Saparita (2004) menunjukkan perkembangan seperti pada Gambar 3.

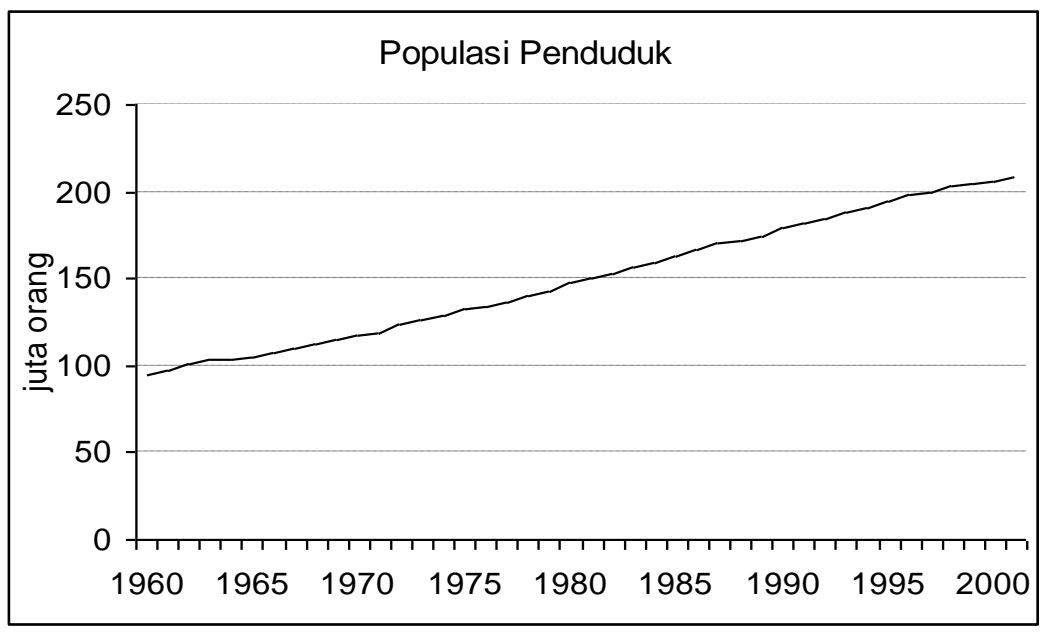

Gambar 2. Perkembangan penduduk Indonesia, 1960-2002 (Sumber: BPS, Statistik Indonesia, berbagai publikasi, diolah kembali) 


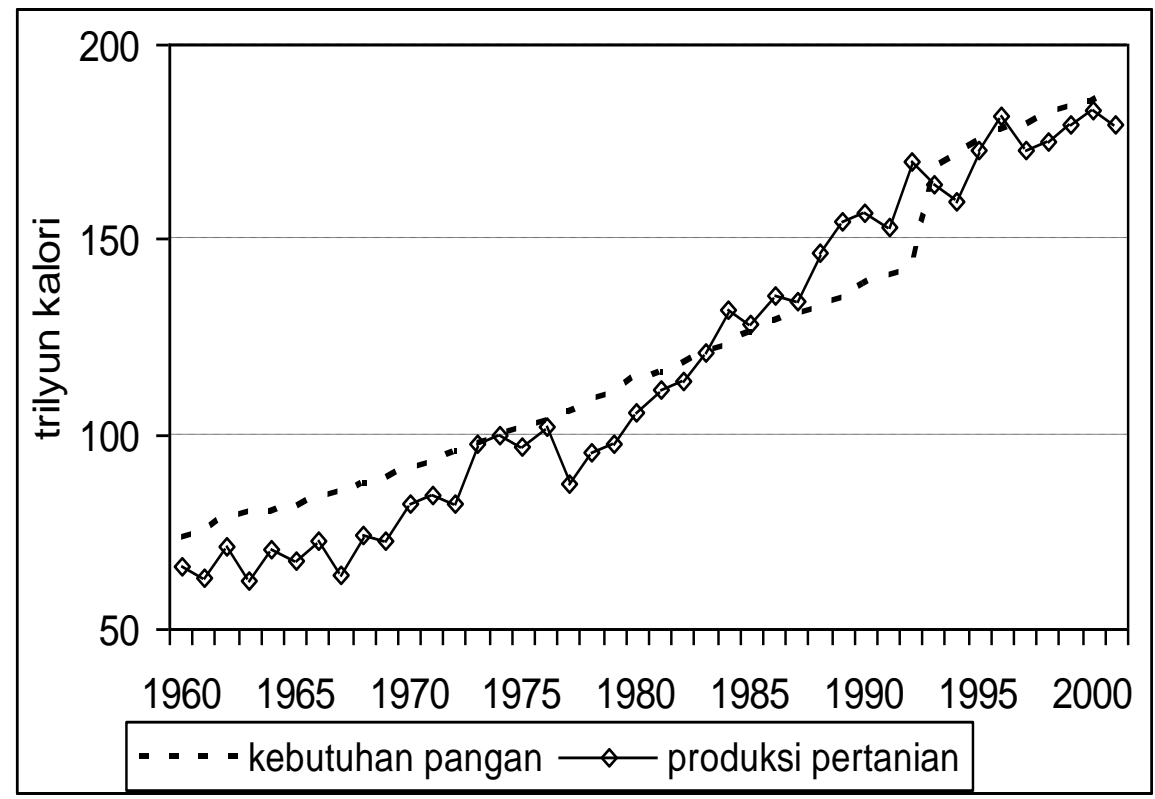

Gambar 3. Perkembangan kebutuhan pangan penduduk dan produksi pertanian Indonesia 1960-2002

Dari Gambar 3 terlihat bahwa bahwa produksi pertanian (tanaman pangan) pada periode 1960-1984 lebih rendah dari kebutuhan pangan penduduk. Artinya, pada periode tersebut kebutuhan pangan tidak tercukupi dari produksi dalam negeri. Pada periode 1984-1993 produksi pertanian domestik melebihi kebutuhan pangan. Program swasembada pangan (beras) terpenuhi. Kebutuhan pangan penduduk dapat dipenuhi oleh produksi sendiri. Setelah 1994 produksi pertanian kembali lebih rendah dari kebutuhan pangan penduduk.

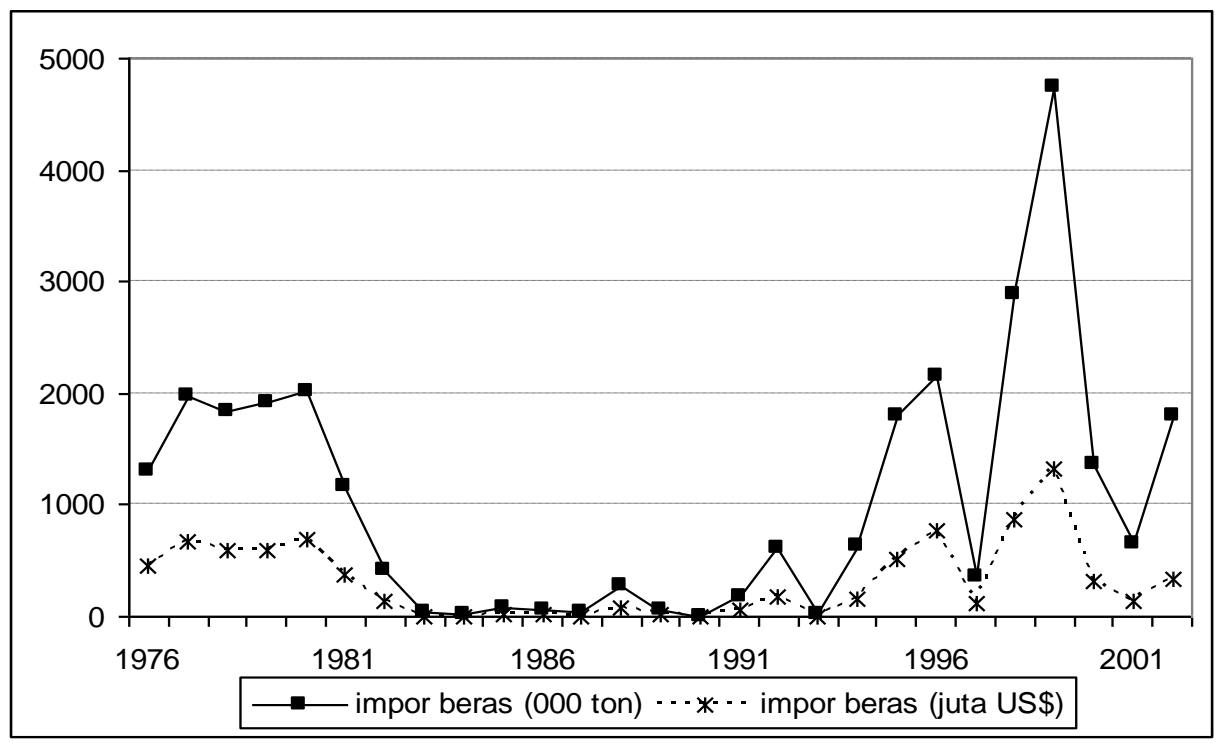

Gambar 4. Perkembangan impor beras untuk kebutuhan konsumsi pangan penduduk Indonesia 1976-2002 (Sumber BPS, Statistik Indonesia, berbagai publikasi) 
Ketika produksi dalam negeri lebih rendah dari kebutuhan pangannya seperti yang terjadi pada periode 1960-1984 dan 1994 sampai sekarang, pemerintah mengimpor bahan pangan pokok (beras) agar kebutuhan tersebut tertutupi. Data perkembangan impor beras yang dilaporkan BPS terlihat pada Gambar 4. Dari Gambar 4 terlihat bahwa impor beras tidak terjadi (sangat kecil terjadi) pada periode 1984-1993.

\section{Proyeksi Perkembangan Penduduk dan Kebutuhan Pangan: 1960-2050}

Proyeksi perkembangan populasi penduduk dan kebutuhan pangan periode 1960-2050 dihasilkan dari simulasi model yang telah dikembangkan Saparita (2004) dan telah diuji kesahihannya. Simulasi dijalankan dengan satu skenario terlebih dahulu, yaitu skenario referensi yang merupakan skenario kebijakan yang berjalan saat ini. Skenario referensi ini mencerminkan bagaimana kondisi perkembangan penduduk Indonesia dan kebutuhan pangan penduduknya apabila kebijakan seperti yang berlangsung saat ini terus berlanjut. Skenario-skenario alternatif dijalankan kemudian ketika akan melihat perubahan yang terjadi apabila diberikan intervensi dari kebijakan baru yang diusulkan.

\section{Proyeksi Perkembangan Penduduk di Indonesia: $1960-2050$}

Hasil simulasi model dengan skenario referensi (kebijakan saat ini) menunjukkan bahwa perkembangan penduduk akan cukup pesat apabila laju peningkatannya seperti yang terjadi saat ini (Gambar 5). Perkembangan tersebut diduga juga akibat meningkatnya angka harapan hidup manusia Indonesia karena meningkatnya kesejahteraan. Pendugaan pengaruh yang positif dari kesejahteraan terhadap angka harapan hidup berdasarkan pada kenyataan, bahwa penduduk yang sejahtera adalah yang berpenghasilan melebihi kebutuhan hidupnya sehingga dapat mengalokasikan penghasilannya untuk kesehatan serta adanya jaminan pasokan pangan yang baik yang dapat mengurangi risiko kematian. Sementara tingkat fertilitas total wanita setelah 2005 diasumsikan mencapai kondisi ideal Indonesia pada nilai 2, yaitu dua anak lahir pada setiap wanita dewasa. Pengaruh faktor migrasi penduduk dianggap sama dengan nol karena jumlah perpindahan penduduk ke dan dari negara lain sangat kecil jika dibandingkan dengan populasi penduduk Indonesia sendiri.

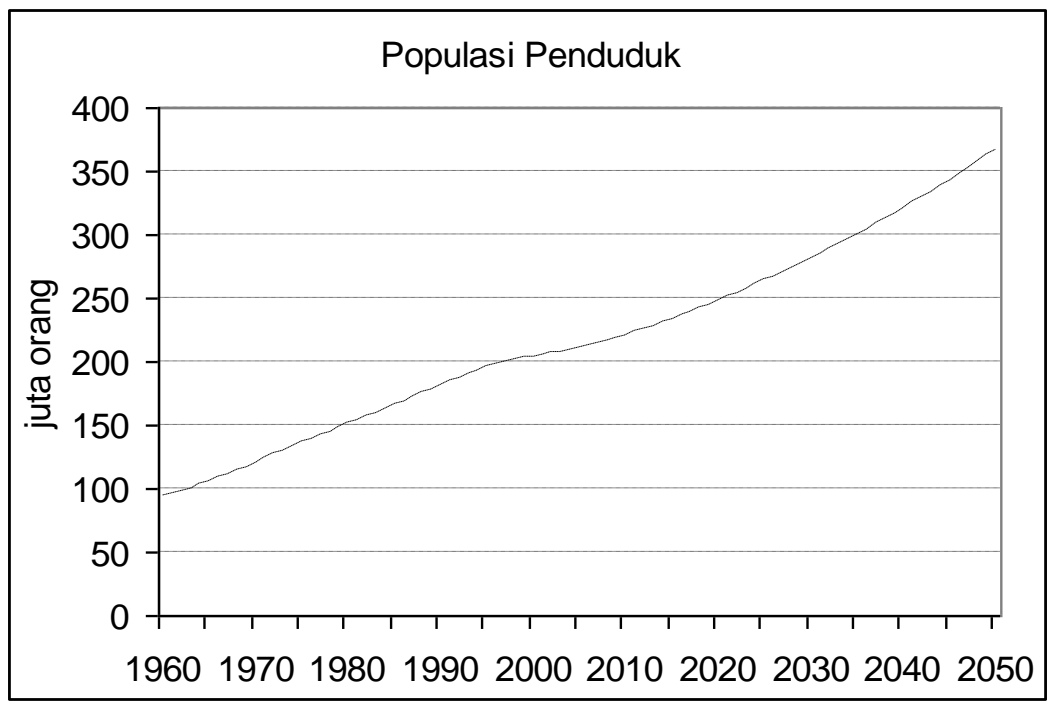

Gambar 5. Proyeksi perkembangan penduduk di Indonesia, 1960-2050 (skenario referensi). 
Dari Gambar 5 terlihat bahwa proyeksi populasi penduduk Indonesia tahun 2050 diprediksi sekitar 350 juta orang. Nilai prediksi ini lebih tinggi dari nilai prediksi yang dihasilkan oleh Sucipto \& Tukiran (1995), yaitu 308,15 juta dengan skenario I, dan 284,30 juta dengan skenario II. Perbedaan tersebut disebabkan karena perbedaan penggunaan beberapa asumsi, yaitu pengaruh kesejahteraan terhadap umur manusia, dan pengaruh umur terhadap populasi penduduk. Asumsi yang diambil oleh Sucipto dan Tukiran, seperti asumsi penurunan fertilitas, penurunan mortalitas, pengabaian migrasi baik karena tanpa sebab, karena perang atau bencana alam, merupakan asumsi yang diambil pula pada model ini. Sucipto \& Tukiran (1995) tidak melibatkan pengaruh variabel kesejahteraan hidup terhadap umur yang nantinya berpengaruh pada peningkatan populasi penduduk. Pada model yang dikembangkan Saparita (2004) yang menjadi dasar penelitian ini, selain asumsi yang dikemukakan oleh Sucipto dan Tukiran tadi, variabel umur yang nilainya senantiasa dinamis karena tergantung pada tingkat kesejahteraan, diasumsikan berpengaruh cukup kuat pada peningkatan jumlah penduduk. Hal ini didasarkan pada fenomena bahwa semakin sejahtera, maka umur manusia semakin panjang, sehingga tingkat kematian penduduk semakin rendah, dan jumlah penduduk menjadi semakin meningkat. Dengan dasar ini, maka nilai prediksi dari model yang dipergunakan pada penelitian ini lebih tinggi dari nilai prediksi model yang dipergunakan Sucipto dan Tukiran (1995). Dugaan perbedaan asumsi ini pula yang menyebabkan perbedaan nilai prediksi pada penggunaan model lain yang berbeda.

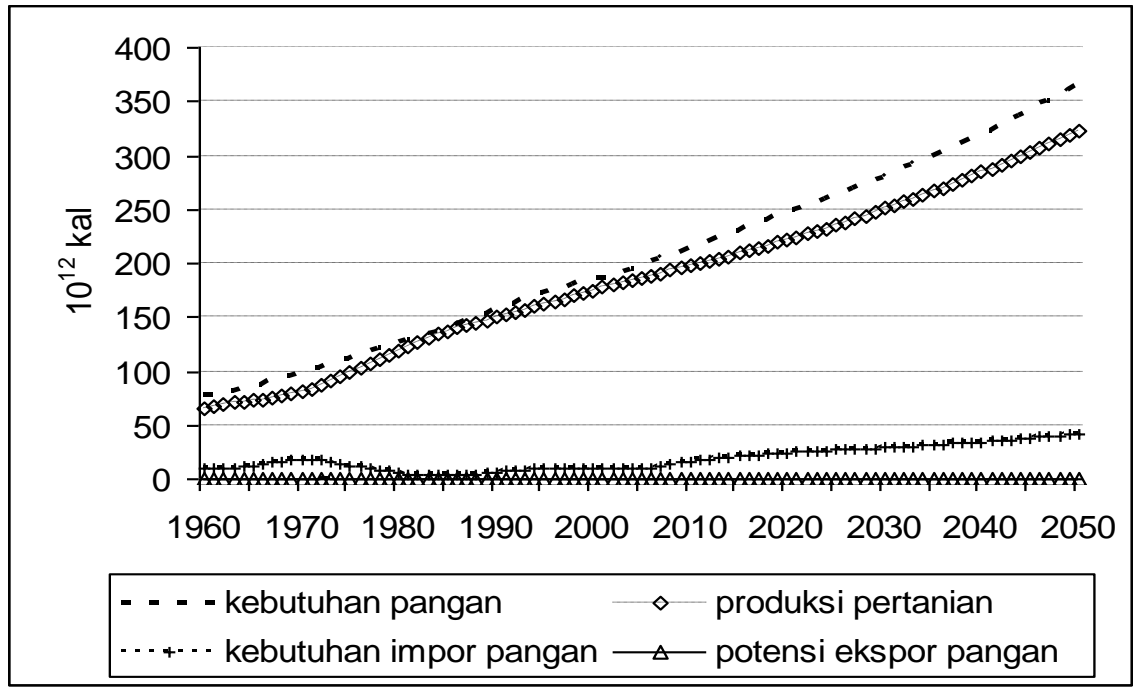

Gambar 6. Proyeksi perkembangan kebutuhan pangan, produksi pertanian, kebutuhan impor dan potensi ekspor pangan, 1960-2050 (skenario referensi)

\section{Proyeksi Perkembangan Kebutuhan Pangan: 1960-2050}

Hasil simulasi model komputer dengan skenario referensi memperlihatkan besarnya kebutuhan pangan penduduk yang senantiasa meningkat dan lebih besar dari produksi yang dihasilkan (Gambar 6). Hal ini disebabkan oleh meningkatnya penduduk seperti pada Gambar 5 di atas, dan kebutuhan pangan per kapita (Gambar 7). Kebutuhan pangan per kapita diasumsikan masih meningkat lagi dari kebutuhan sekarang yang telah dihitung LIPI (2000). Apabila kondisi seperti sekarang terus berlangsung, maka hal tersebut diduga akan berdampak pada peningkatan kebutuhan impor yang pada akhirnya berdampak pada realcisasi impor sebagai cara cepat dan 
mudah dalam memenuhi kebutuhan pangan penduduk, sementara potensi ekspor pangan dari Indonesia diduga senantiasa nol (Gambar 6).

Pada model yang dikembangkan, cadangan sumber kalori penduduk dianggap tidak ada (diabaikan) karena data empiris menunjukkan bahwa ekspor beras nol, dan impor beras cukup besar. Begitu pula pengaruh permintaan eksternal akan ekspor dan pengaruh internal akan impor dalam model yang dikembangkan diabaikan mengingat ekspor dan impor yang dimodelkan didasarkan pada syarat kecukupan pangan.

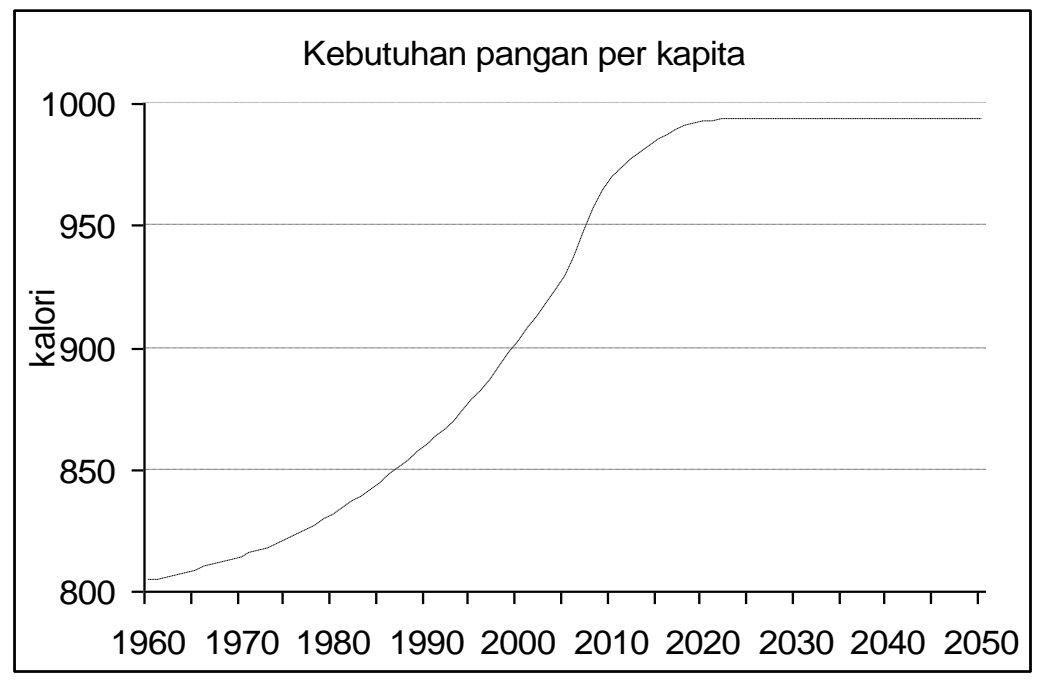

Gambar 7. Proyeksi kebutuhan pangan per kapita, 1960-2050 (skenario referensi).

Proyeksi kebutuhan pangan yang dihasilkan (Gambar 7) berbeda dengan kebutuhan pangan yang diproyeksikan oleh Sucipto dan Tukiran (1995). Seperti juga halnya perbedaan proyeksi penduduk, perbedaan proyeksi kebutuhan pangan juga disebabkan oleh perbedaan penggunaan asumsi. Sucipto dan Tukiran (1995) mengasumsikan kebutuhan beras per kapita sampai tahun 2055 dianggap sama dengan kebutuhan beras per kapita yang telah berjalan sekarang, yaitu 12,6 $\mathrm{kg} / \mathrm{jiwa} / \mathrm{bulan}$ untuk pekerja lajang, dan 9,4 kg/jiwa/bulan untuk pekerja dengan satu istri dan dua anak, atau $9 \mathrm{~kg} / \mathrm{jiwa} /$ bulan untuk pekerja dengan tiga anak. Model yang dipergunakan pada penelitian ini mengasumsikan bahwa kebutuhan pangan per kapita (kalori per orang per tahun) diasumsikan meningkat secara dinamis karena meningkatnya kesejahteraan hidup. Semakin sejahtera kehidupan manusia, semakin meningkat kalori makanan yang dikonsumsi, sampai pada taraf kesejahteraan tertentu, ketika kebutuhan dasar telah terpenuhi secara optimal (Gambar 7).

Bagi Indonesia, yang bukan negara 'kaya', kondisi ketika pasokan pangan senantiasa tergantung pada impor akan sangat memprihatinkan. Ketika cadangan devisa tersedia dari pendapatan nasional, tentu saja tidak akan mengganggu stabilitas ekonomi negara. Namun ketika cadangan devisa didapatkan dari dana pinjaman, hal tersebut akan mengakibatkan stabilitas ekonomi terganggu, sehingga ketahanan pangan menjadi sesuatu yang sulit dicapai.

Untuk mengantisipasi kondisi yang tidak diinginkan, salah satunya adalah rawan pangan, maka berbagai kebijakan yang dapat memperbaiki kondisi tersebut dapat dilaksakan oleh pemerintah. Model yang dibangun mempunyai kemampuan melakukan simulasi berbagai alternatif kebijakan yang dapat dijalankan untuk mengatasi rawan pangan, sebelum kebijakan tersebut 
diterapkan di lapangan (ex-ante). Pada penelitian ini telah diujicobakan berbagai alternatif kebijakan yang mungkin dapat dilaksanakan oleh pemerintah.

\section{Alternatif Kebijakan Pemenuhan Kebutuhan Pangan menuju Ketahanan Pangan Nasional yang Tangguh: Skenario Alternatif}

Pada kajian ini usulan kebijakan yang diajukan adalah dua kebijakan yang telah diusulkan Saparita (2004) yang berkaitan dengan pembangunan pertanian, yaitu peningkatan produksi pertanian melalui perluasan area panen dengan meningkatkan intensitas tanam (skenario alternatif I), serta melalui peningkatan produktivitas lahan dengan adopsi teknologi (skenario alternatif 2). Lima alternatif kebijakan tambahan yang diusulkan pada kajian ini (skenario akternatif III-VII), ditujukan untuk mengatasi kekurangan pangan dari produksi dalam negeri. Skenario alternatif III yang diusulkan kebijakan peningkatan produksi dengan meningkatkan intensitas lahan dan adopsi teknologi. Kebijakan kependudukan pada skenario I-III diasumsikan berjalan seperti yang telah berjalan sekarang.

Skenario alternatif IV-VII adalah diujicobakan untuk kebijakan penurunan angka kelahiran, melalui berbagai informasi peningkatan kualitas hidup generasi selanjutnya, tanpa menyentuh pembangunan pertanian seperti skenario I-III, artinya untuk skenario alternatif IV intensitas tanam dan produktivitas pertanian tidak ditingkatkan, jadi seperti yang terjadi saat ini. Pada skenario alternatif $\mathrm{V}$, selain program penurunan angka kelahiran, juga diujicobakan peningkatan produksi melalui intensitas tanam saja, sedangkan pada skenario alternativ $\mathrm{VI}$, program penurunan angka kelahiran dilakukan dengan peningkatan produktivitas pertanian saja tanpa peningkatan intensitas tanam. Pada skenario alternatif VII, diujicobakan kebijakan terpadu antara penurunan angka kelahiran, peningkatan intensitas tanam, dan peningkatan produktivitas pertanian melalui adopsi teknologi.

\section{Skenario Alternatif I: Peningkatan Intensitas Tanam}

Seperti yang telah diusulkan Saparita (2004), peningkatan produksi pertanian untuk memenuhi kebutuhan pangan dapat dilakukan dengan meningkatkan intensitas tanam. Selama 42 tahun (1960-2002) rata-rata intensitas tanam di Indonesia masih rendah, baru sebesar 1,32 kali. Dari sejarah masa lalu, intensitas tanam tertinggi telah terjadi pada tahun 1992, sebesar 1,57 kali dalam setahun. Apabila program peningkatan intensitas dijalankan pada tahun 2005 mencapai angka 1,57 seperti yang terjadi pada tahun 1992, maka luas panen akan meningkat dan produksi pertanian meningkat. Dengan peningkatan intensitas tanam seperti tahun 1992, produksi pertanian yang dihasilkan (Gambar 8) masih belum dapat memenuhi kebutuhan pangan penduduk yang tinggi karena pesatnya perkembangan penduduk seperti pada Gambar 5 di atas. Kebutuhan impor pangan yang akan berakibat pada realisasinya masih di atas nol, sementara potensi ekspor yang muncul ketika tidak ada kebutuhan impor hanya terlihat pada periode 2005-2015. Skenario alternatif I ini masih belum memberikan solusi yang memadai untuk kecukupan pangan dalam program ketahanan pangan yang tangguh. 


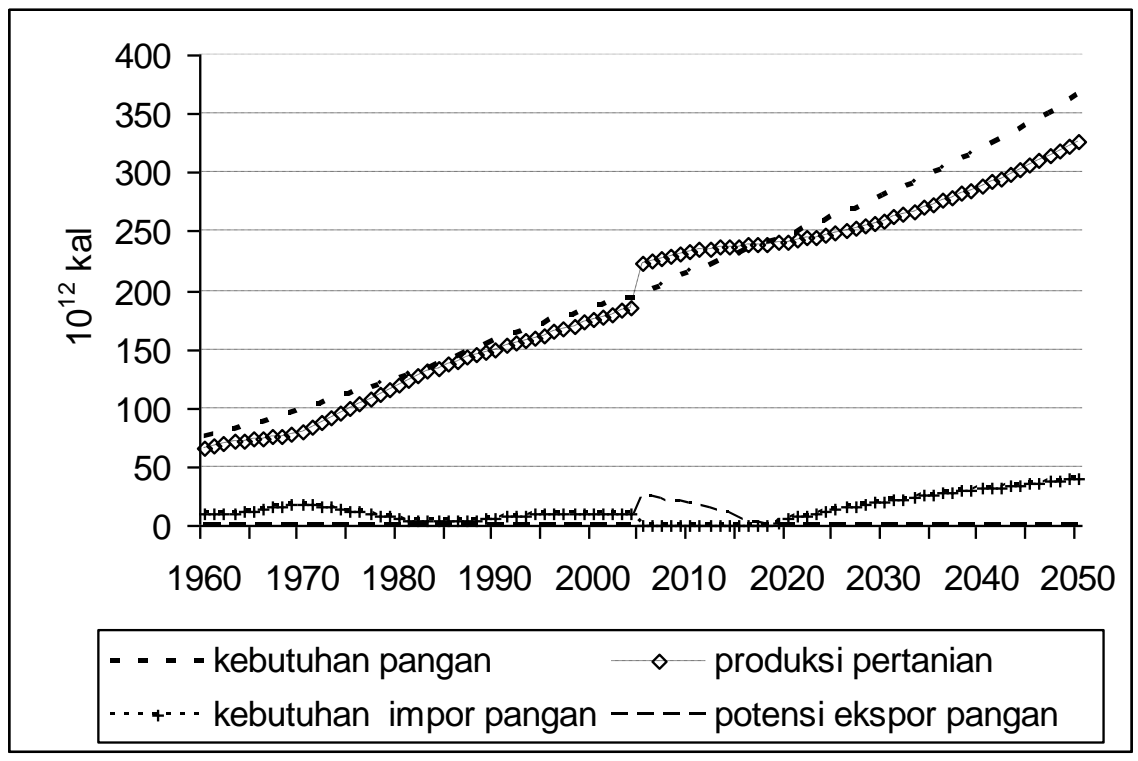

Gambar 8. Proyeksi perkembangan kebutuhan pangan, produksi pertanian, kebutuhan impor dan potensi ekspor pangan, 1960-2050 (skenario alternatif I)

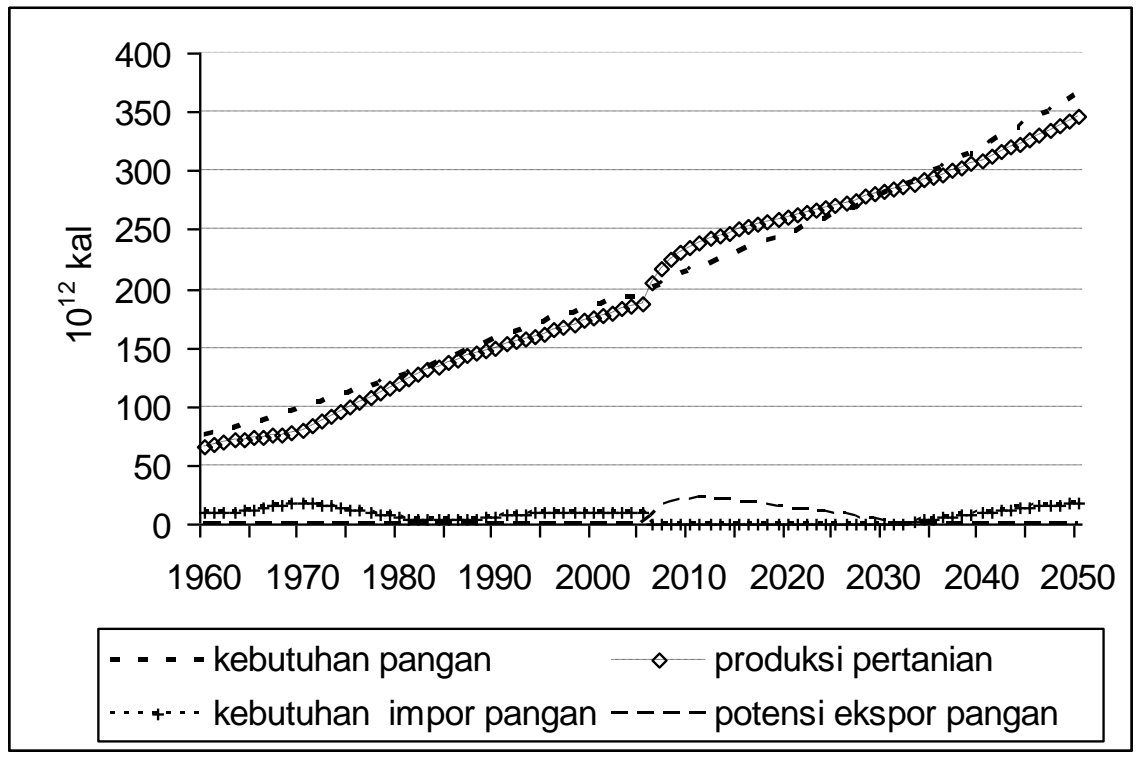

Gambar 9. Proyeksi perkembangan kebutuhan pangan, produksi pertanian, kebutuhan impor dan potensi ekspor pangan, 1960-2050 (skenario alternatif II)

\section{Skenario Alternatif II: Peningkatan Adopsi Teknologi}

Penggunaan teknologi unggul di sektor pertanian seperti penggunaan benih unggul dan pemakaian pupuk, serta penggunaan bio teknologi, telah terbukti dapat meningkatkan produktivitas lahan pertanian (Saparita, 2004). Apabila penggunaan benih unggul dan pupuk ditingkatkan, sehingga produktivitas lahan pada tahun 2010 sama dengan produktivitas lahan di Jepang pada tahun 1995 (15092 kkal/hektar), meskipun intensitas tanam tidak meningkat, maka peningkatan 
produktivitas dapat meningkatkan produksi (Gambar 9). Namun ternyata, dengan peningkatan produktivitas seperti itu, produksi pertanian yang dihasilkan masih belum juga dapat memenuhi kebutuhan pangan penduduk. Kebutuhan impor pangan masih di atas nol, sementara potensi ekspor yang muncul ketika tidak ada kebutuhan impor hanya terlihat pada periode 2005-2025, hanya sepuluh tahun lebih panjang dari skenario alternatif I. Skenario alternatif II juga masih belum memberikan solusi yang memadai untuk program ketahanan pangan yang tangguh.

\section{Skenario Alternatif III: Peningkatan Intensitas Tanam dan Adopsi Teknologi}

Alternatif kebijakan lain yang diujicobakan adalah memadukan program peningkatan intensitas tanam dan adopsi teknologi agar produksi pertanian semakin meningkat mulai tahun 2005 ini, sementara program kependudukan diasumsikan masih berjalan seperti sekarang, yang perkembangannya diprediksi seperti pada Gambar 5 di atas. Dengan memadukan dua program usulan tersebut, simulasi model komputer menunjukkan adanya peningkatan produksi yang memadai untuk memenuhi kebutuhan pangan domestik seperti terlihat pada Gambar 10. Apabila kebijakan pembangunan pertanian memadukan program peningkatan intesitas tanam dan adopsi teknologi seperti ini dilakukan, maka sampai tahun 2050, Indonesia masih dapat melaksanakan swasembada pangan. Namun apabila diperhatikan, potensi ekspor yang terjadi karena tidak ada kebutuhan impor ternyata menunjukkan penurunan. Hal ini berarti akan terjadi rawan pangan apabila kebijakan yang diusulkan ini tidak diperbaiki di masa mendatang. Skenario alternatif III memberikan solusi untuk program ketahanan pangan sampai 2050.

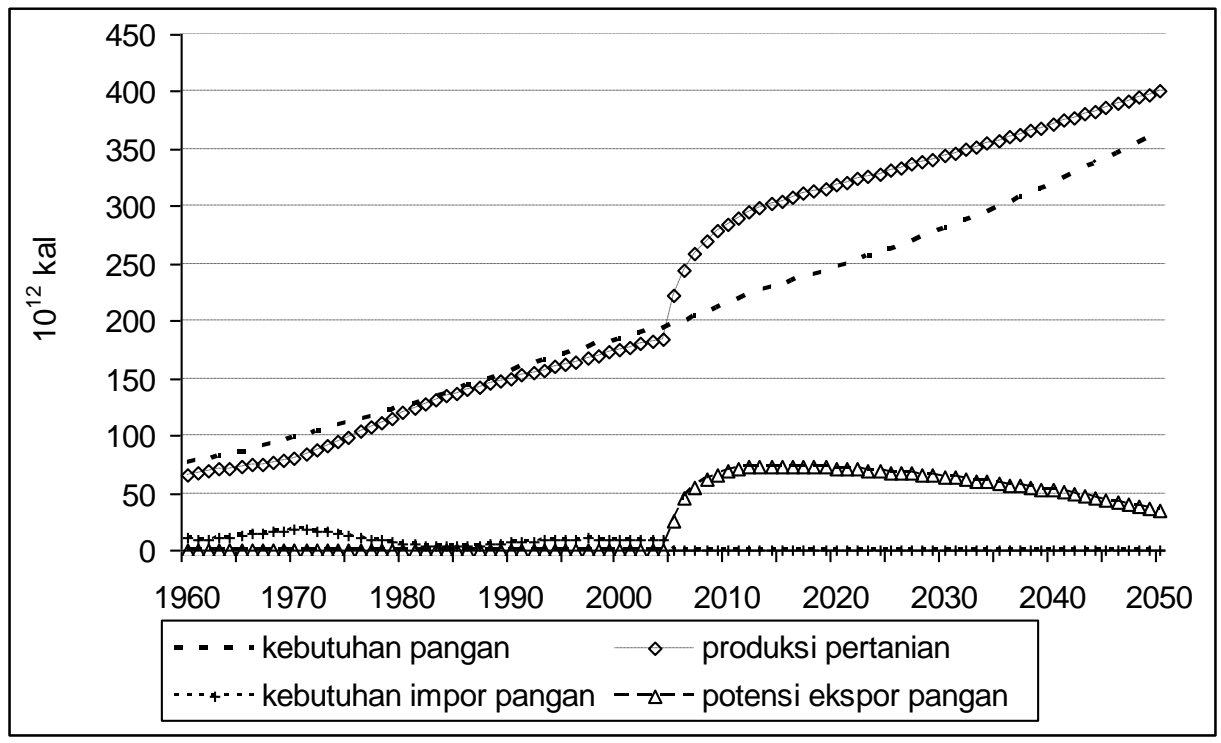

Gambar 10. Proyeksi perkembangan kebutuhan pangan, produksi pertanian, kebutuhan impor dan potensi ekspor pangan, 1960-2050 (skenario alternatif III)

\section{Skenario Alternatif IV: Penurunan Angka Kelahiran}

Kebijakan penurunan angka kelahiran yang lebih kecil dari dua pada dasarnya sangat dikhawatirkan, karena diduga akan memberi dampak pada tatanan kehidupan sosial di Indonesia. Jika mengacu pada 'fasilitas' model yang dikembangkan Saparita (2004), skenario alternatif untuk kebijakan penurunan/penekanan angka kelahiran dapat saja dijalankan, bahkan pada kondisi 
ekstrim sekalipun, seperti tingkat kelahiran nol, atau seperti yang berlaku di pemerintahan Cina sekarang, yaitu satu anak untuk satu keluarga.

Untuk keperluan penelaahan kondisi perkembangan penduduk, hubungannya dengan kebutuhan pangan yang berakibat pada ketahanan pangan penduduk, maka alternatif kebijakan penurunan angka kelahiran diujicobakan. Pada simulasi komputer kebijakan program kependudukan dicobakan melalui penurunan jumlah anak yang dilahirkan wanita dewasa. Pada uji coba model, total fertility rate seorang wanita dewasa diasumsikan mencapai angka 1,35, yaitu dalam 100 wanita dewasa melahirkan anak 135 pada tahun 2006. Angka ini masih lebih tinggi dari angka kelahiran yang terjadi di Cina (satu anak untuk satu wanita dewasa). Sementara itu kebijakan pembangunan pertanian diasumsikan masih sama dengan kondisi yang sekarang berlangsung, intensitas tanam dan adopsi teknologi tidak meningkat. Dengan alternatif kebijakan seperti itu, maka hasil simulasi komputer terlihat pada Gambar 11-12.

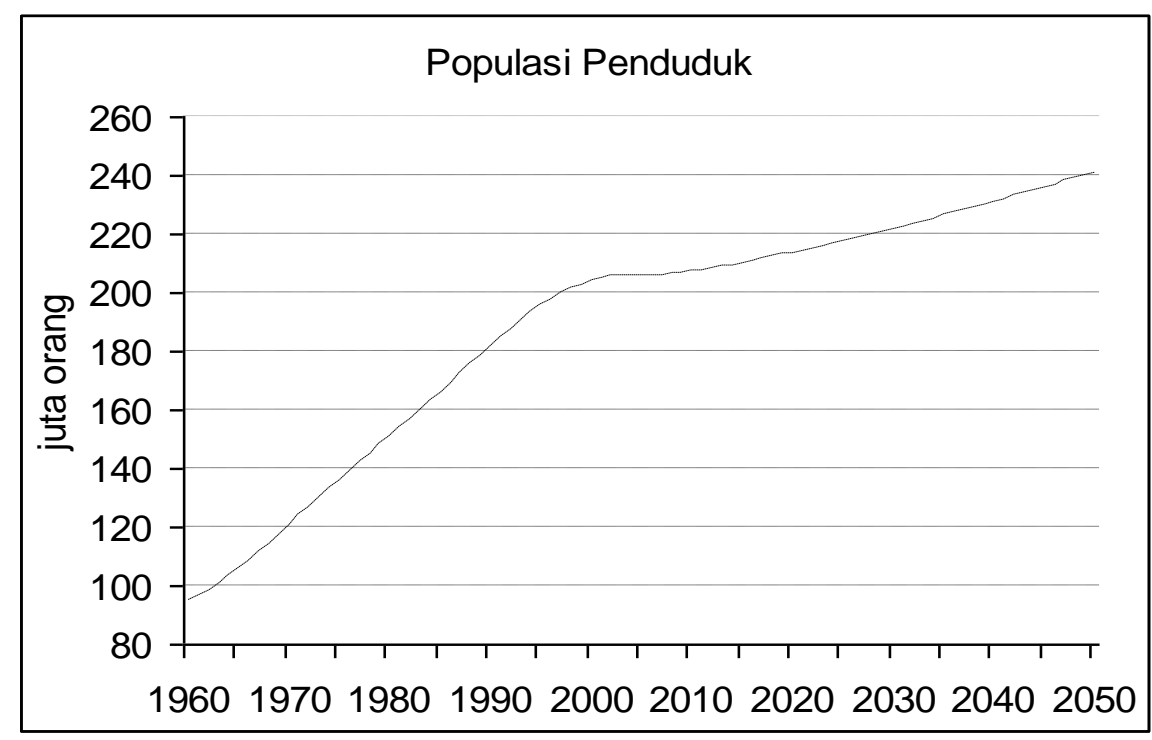

Gambar 11. Proyeksi perkembangan penduduk di Indonesia, 1960-2050 (skenario alternatif IV)

Dari Gambar 11 terlihat bahwa penekanan angka kelahiran sejak 2006 dapat menekan perkembangan penduduk secara signifikan jika dibandingkan dengan yang tanpa program penurunan angka kelahiran seperti pada Gambar 5 di atas. Dengan perkembangan penduduk yang lebih terkendali, maka produksi yang dihasilkan seperti pada skenario referensi (Gambar 6), dapat memenuhi kebutuhan pangan penduduk, bahkan dapat mengalokasikan sebagian hasil produksinya untuk ekspor pangan (Gambar 12). Meskipun belum besar, namun potensi ekspor pangan terlihat semakin meningkat. Jadi program penurunan angka kelahiran sebetulnya cukup efektif untuk menekan laju peningkatan kebutuhan pangan, sehingga produksi yang dihasilkan cukup untuk memenuhi kebutuhan pangan domestik, dan ketahanan pangan tercapai. 


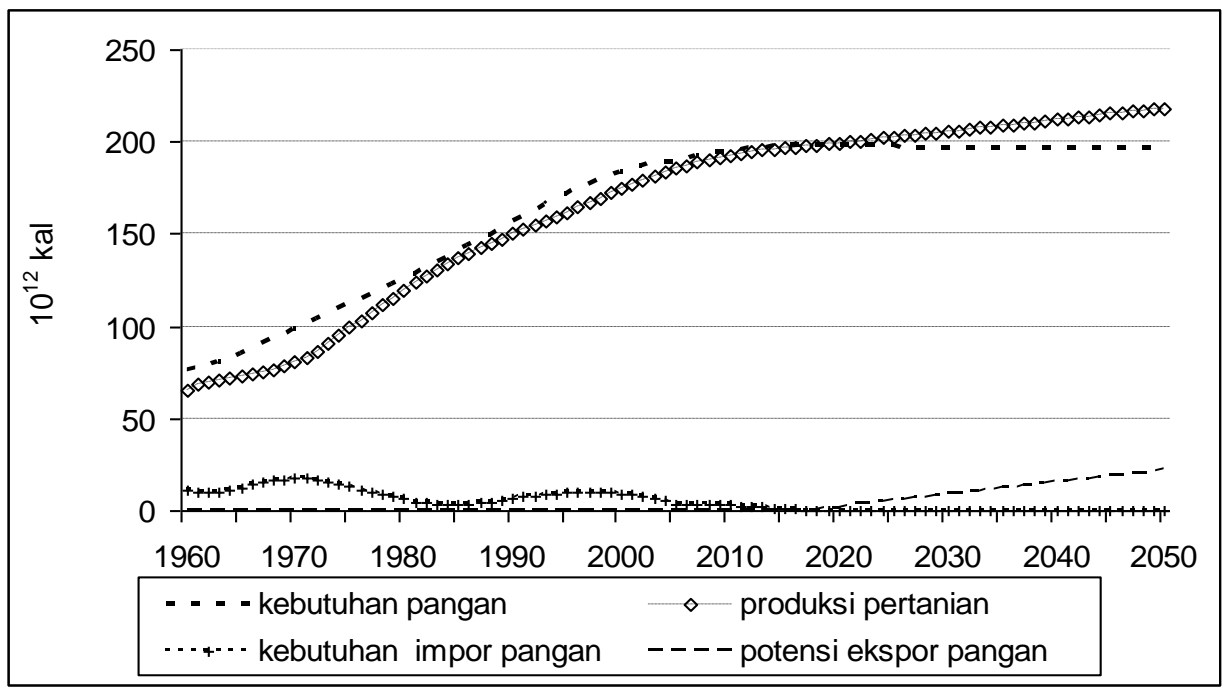

Gambar 12. Proyeksi perkembangan kebutuhan pangan, produksi pertanian, kebutuhan impor dan potensi ekspor pangan, 1960-2050 (skenario alternatif IV)

5. Skenario Alternatif V: Program Penurunan Angka Kelahiran dan Peningkatan Intensitas Tanam

Penurunan angka kelahiran yang dipadukan dengan peningkatan intensitas tanam tentu saja akan meningkatkan produksi jauh melebihi kebutuhan pangannya. Hasil simulasi model komputer dengan kebijakan ini terlihat pada Gambar 13, dengan perkembangan penduduk seperti pada Gambar 11 di atas. Seperti halnya alternatif kebijakan V, program penurunan angka kelahiran dipadu dengan peningkatan intensitas tanam cukup baik untuk mengantar peningkatan produksi dalam memenuhi kebutuhan pangan domestik, dan ketahanan pangan.

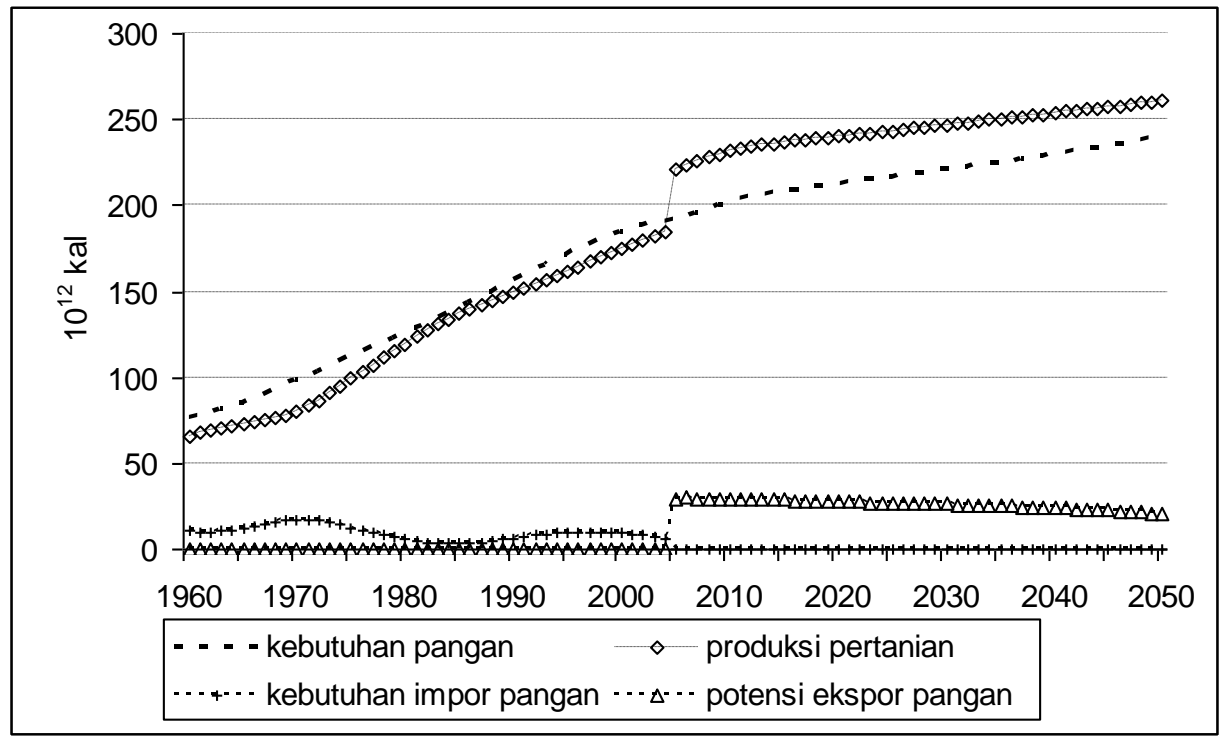

Gambar 13. Proyeksi perkembangan kebutuhan pangan, produksi pertanian, kebutuhan impor dan potensi ekspor pangan, 1960-2050 (skenario alternatif V) 


\section{Skenario Alternatif VI: Program Penurunan Angka Kelahiran dengan Peningkatan Adopsi Teknologi}

Seperti halnya alternatif kebijakan $\mathrm{V}$, penurunan angka kelahiran yang dipadukan dengan peningkatan adopsi teknologi dapat meningkatkan produksi jauh melebihi kebutuhan pangannya. Hasil simulasi model komputer dengan kebijakan ini terlihat pada Gambar 14, dengan perkembangan penduduk seperti pada Gambar 11. Program penurunan angka kelahiran dengan peningkatan adopsi teknologi terlihat lebih baik dari alternatif skenario $\mathrm{V}$ dalam mengantar peningkatan produksi untuk memenuhi kebutuhan pangan domestik, sehingga ketahanan pangan tercapai. Kelebihan kebijakan skenario VI adalah memberikan gambaran akan adanya peningkatan potensi ekspor pangan. Hal ini berarti laju peningkatan produksi pertanian lebih tinggi dari laju kebutuhan pangan.

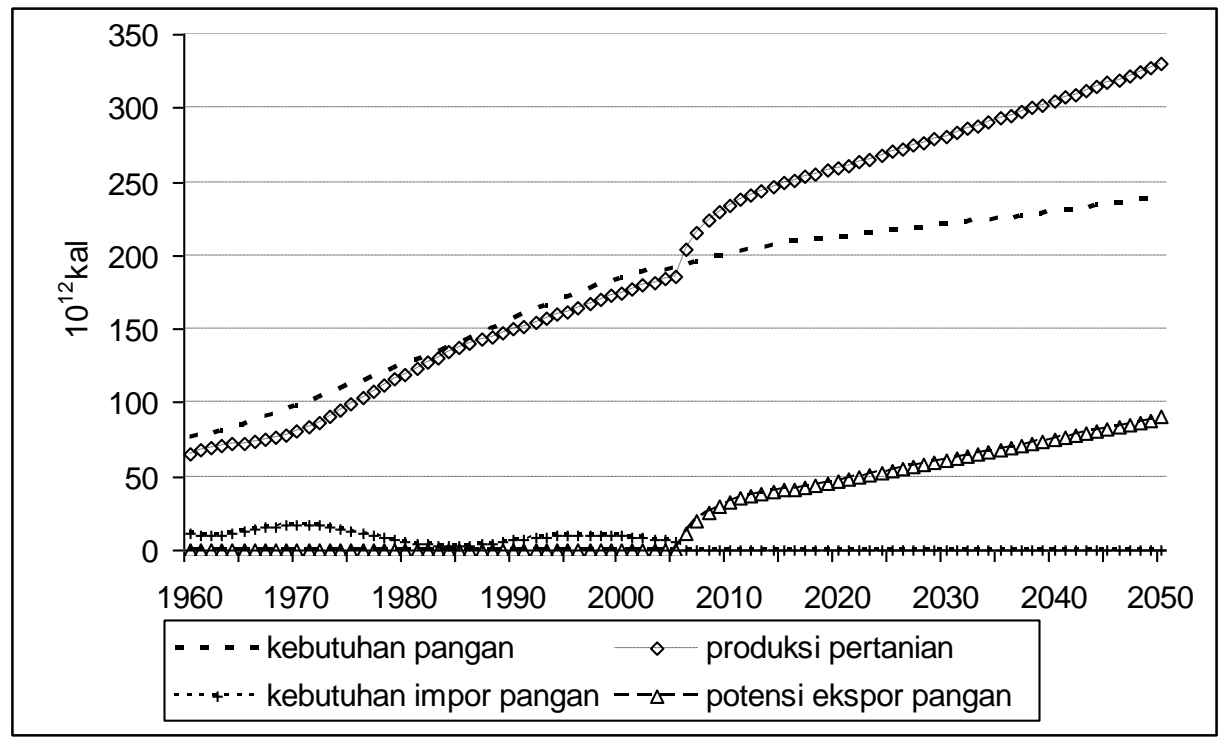

Gambar 14. Proyeksi perkembangan kebutuhan pangan, produksi pertanian, kebutuhan impor dan potensi ekspor pangan, 1960-2050 (skenario alternatif VI)

7. Skenario Alternatif VII: Program Penurunan Angka Kelahiran dengan Peningkatan Intensitas Tanam dan Adopsi Teknologi

Penurunan angka kelahiran yang dipadukan dengan peningkatan intensitas tanam dan adopsi teknologi adalah skenario alternatif terakhir yang diajukan. Hasil simulasi model menunjukkan peningkatan produksi yang jauh melebihi kebutuhan pangan (Gambar 15). Hasil simulasi model komputer dengan kebijakan yang terlihat pada Gambar 15 dengan perkembangan penduduk seperti pada Gambar 11 mengindikasikan bahwa program kebijakan terpadu yang diajukan ini merupakan program yang paling baik dari seluruh alternatif yang diujicobakan. Program dapat mengantar pada peningkatan produksi dalam memenuhi kebutuhan pangan domestik, untuk mencapai ketahanan pangan yang tangguh.

Hasil simulasi model komputer dari berbagai skenario yang diajukan di atas mengindikasikan bahwa sumber daya alam Indonesia masih memungkinkan untuk memenuhi pangan penduduk secara mandiri (swasembada pangan). Masalah yang muncul adalah ketika produksi domestik melebihi kebutuhan pangan, yang dalam penelitian ini direpresentasikan oleh potensi ekspor pangan, maka kelebihan produksi tersebut pada kondisi ril sekarang sulit untuk diekspor, mengingat harga 
pangan internasional (khususnya beras) jauh lebih rendah dari harga domestik, sehingga kegiatan ekspor pangan tidak akan menguntungkan. Jadi peningkatan produksi secara nyata belum tentu dapat merealisasikan ekspor untuk meningkatkan pendapatan.

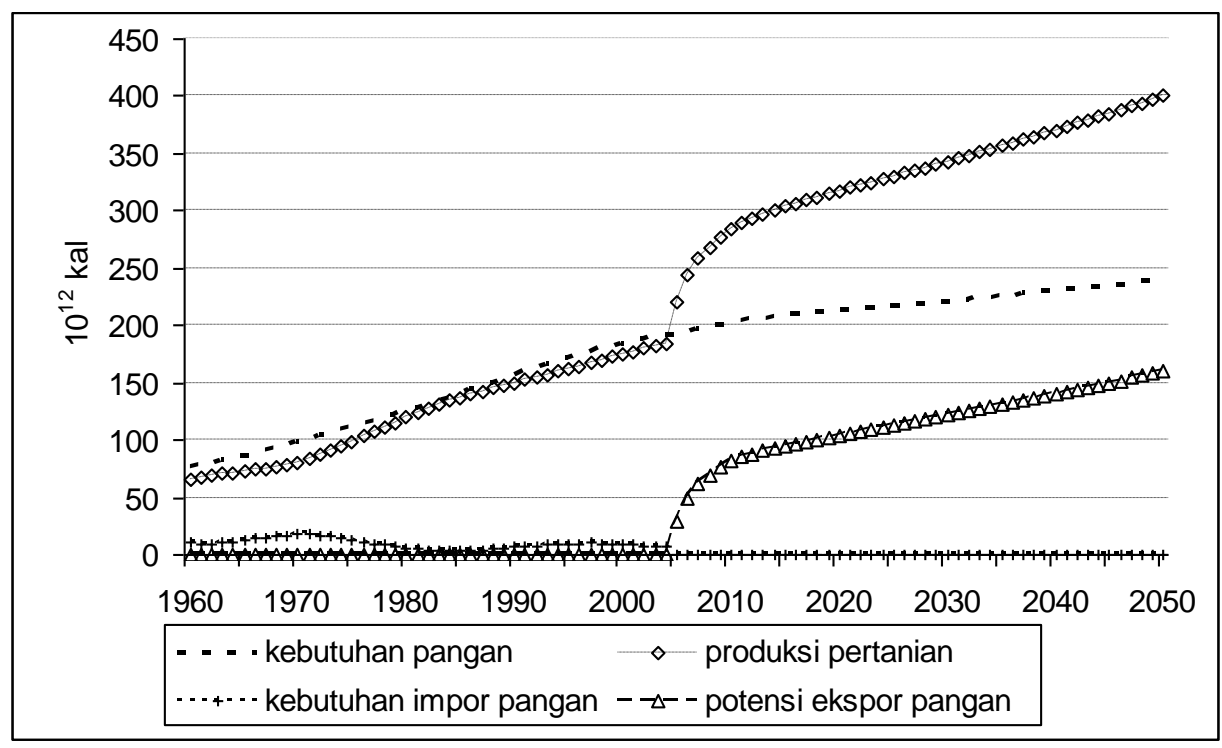

Gambar 15. Proyeksi perkembangan kebutuhan pangan, produksi pertanian, kebutuhan impor dan potensi ekspor pangan, 1960-2050 (skenario alternatif VII)

Seperti diuraikan di atas, kebijakan penekanan penduduk melalui program penurunan angka kelahiran secara tertencana diduga sangat sulit dilakukan. Salah satu upaya penurunan angka kelahiran adalah dengan program tidak langsung, yaitu melalui peningkatan pendapatan masyarakat, khususnya masyarakat pertanian karena sejauh ini mereka merupakan masyarakat yang mendominasi bangsa ini.

Upaya peningkatan pendapatan di sektor pertanian adalah melalui peningkatan nilai tambah. Agar produksi pertanian, baik untuk kegiatan domestik maupun ekspor, dapat meningkatkan pendapatan pertanian, maka seperti yang diusulkan Saragih (1998), kegiatan agro-based industry dapat dijalankan agar nilai tambah produksi pertanian bertambah tinggi. Pendapatan yang meningkat dapat meningkatkan kesejahteraan penduduk, yang dapat mempengaruhi penurunan laju perkembangan penduduk. Karena penduduk yang sejahtera dapat meningkatkan pendidikannya, sehingga kesadaran akan pentingnya kualitas hidup dapat terbangun, yang pada akhirnya penekanan kelahiran untuk mendapatkan keluarga yang lebih berkualitas dari pada kuantitas dapat dilakukannya dengan kesadaran sendiri. Pada akhirnya ketahanan pangan yang tangguh dapat tercapai. Negara-negara yang telah maju dapat membuktikan bahwa kesejahteraan yang meningkat dapat menekan laju pertumbuhan penduduk.

\section{KESIMPULAN}

Populasi penduduk Indonesia memang berkembang cukup pesat, dan diduga akan terus berkembang pesat, khususnya sampai 2050. Perkembangan penduduk menentukan besarnya kebutuhan pangan, namun kebutuhan pangan sebaiknya dipenuhi oleh produksi domestik sehingga tidak tergantung pada impor yang memerlukan devisa banyak. Untuk pemenuhan kebutuhan pangan 
dari produksi domestik, maka alternatif kebijakan terpadu, yaitu peningkatan produksi pertanian melalui peningkatan intensitas tanam dan adopsi teknologi diajukan agar produksi domestik melebihi kebutuhan pangan. Untuk mencapai ketahanan pangan yang tangguh, kebijakan peningkatan produksi saja tidak cukup. Peningkatan nilai tambah pertanian harus diprioritaskan agar pendapatan pertanian meningkat sehingga dapat meningkatkan pendapatan dan kesejahteraan masyarakat yang pada gilirannya dapat meningkatkan pendidikan dan meningkatkan kesadaran akan pentingnya kualitas hidup, dan laju perkembangan penduduk dapat ditekan.

\section{UCAPAN TERIMA KASIH}

Penulis mengucapkan terima kasih kepada Prof. Dr. Burhan Arief, Ir.; Dr. Ronnie S. Natawidjaja, Ir. M.Sc.; Dr. Amru Hydari Nazif, M.Sc.; Dr. Muhammad Tasrif, Ir. M.Eng.Sc.; atas segala kontribusinya dalam penelitian yang dilaksakanan. Terima kasih pula penulis sampaikan kepada Lembaga IImu Pengetahuan Indonesia atas fasilitas yang diberikan selama penulis menjalankan penelitian ini

\section{REFERENSI}

BPS. (1973). Statistik Indonesia 1992. Jakarta: Biro Pusat Statistik.

BPS. (1999). Statistik Indonesia 1998. Jakarta: Biro Pusat Statistik.

LIPI. (1993). Widyakarya Pangan dan Gizi V. Jakarta: Lembaga IImu Pengetahuan Indonesia.

LIPI. (2000). Widyakarya Pangan dan Gizi VII,.Jakarta: Lembaga IImu Pengetahuan Indonesia.

Saparita, R., Arief, B., Nazif, A. H., Natawidjadja, R. S., \& Tasrif, M. (2003). System dynamics model of sustainable agriculture: The case of Indonesia. International Conference on Redesigning Sustainable Development on Food and Agricultural System for Developing Countries. Yogyakarta: Gadjahmada University.

Saparita, R. (2004). Model transformasi pertanian di Indonesia menggunakan pendekatan system Dynamics. Disertasi S3. Program Pascasarjana Universitas Padjadjaran. Tidak Dipublikasikan.

Saragih, B. (1998). Agribisnis: Paradigma baru pembangunan ekonomi berbasis pertanian. Kumpulan pemikiran. Bogor: Pusat Studi Pembangunan Lembaga Penelitian Institut Pertanian Bogor.

Simatupang, P. (1989). Perubahan struktur produksi dan pengaruh potensi deregulasi pada subsektor tanaman pangan dalam E. Pasandaran, dkk. (Penyunting). Perkembangan Struktur produksi, ketenagakerjaan dan pendapatan rumah tangga pedesaan. Prosiding Patanas. Bogor. hal.13-41.

Sucipto, T. \& Tukiran. (1995). Proyeksi penduduk Indonesia tahun 1990-2050. Yogyakarta: Pusat Penelitian Kependudukan Universitas Gajah Mada. 